\title{
Young beneficiaries' routes off benefits through labour market integration: the case of Germany
}

\author{
Brigitte Schels
}

Accepted: 1 July 2011 / Published online: 23 July 2011

(C) Institut für Arbeitsmarkt- und Berufsforschung 2011

\begin{abstract}
The study explores routes off benefits through labour market integration for young adults in Germany. Policies for young people are focused on a rapid integration into employment or training to prevent long-term benefits dependency. The causes of long-term benefits receipt can be related to poor labour market opportunities. But in political and public discourse, long-term benefits dependency is most widely regarded as the consequence of young adults' low labour supply. The article examines the labour market transitions of 650 beneficiaries aged 18 to 24 . The analysis combines survey data on beneficiaries in Germany and longitudinal register data for 2005 to 2007. Though most of the young adults surveyed enter employment or vocational training, a high percentage continues to receive benefits. Long-term benefits receipt is related to low levels of qualifications and young parenthood; there is no evidence for young people resigning themselves to benefits receipt.
\end{abstract}

Keywords welfare unemployment young adulthood duration analysis

JEL Classification I38 · J64 · C41

Die Wege junger Erwachsener aus dem Arbeitslosengeld-II-Bezug durch eine Arbeitsmarktintegration

Zusammenfassung Die Studie geht der Frage nach, welche jungen Arbeitslosengeld-II-Empfänger mit Aufnahme

B. Schels $(\bowtie)$

Institut für Arbeitsmarkt- und Berufsforschung (IAB),

Regensburger Straße 104, 90478 Nürnberg, Germany

e-mail: brigitte.schels@iab.de einer Erwerbstätigkeit oder Ausbildung den Leistungsbezug beenden können. In der Grundsicherung für Arbeitssuchende wird ein besonderer Fokus auf die Förderung unter 25-Jähriger gelegt; Ziel ist, mit einer möglichst schnellen Integration in Ausbildung oder Beschäftigung einem Langzeitbezug im späteren Erwachsenenalter vorzubeugen. In der öffentlichen und politischen Diskussion in Deutschland wird vor allem argumentiert, dass Langzeitbezug von Arbeitslosengeld II auf die geringe Erwerbsbereitschaft von jungen Erwachsenen zurückzuführen sei. Dennoch kann längerer Arbeitslosengeld-II-Bezug auch durch geringe Arbeitsmarktchancen von benachteiligten jungen Erwachsenen entstehen. Die Studie betrachtet die Übergänge von rund 650 18- bis 24-jährigen Arbeitslosengeld-II-Empfängern in Ausbildung und Beschäftigung auf Basis von Befragungsdaten und Längsschnittdaten der Arbeitsverwaltung für die Jahre 2005 bis 2007. Die Ergebnisse zeigen, dass zwar die meisten der betrachteten jungen Erwachsenen im Beobachtungszeitraum eine Arbeit oder Ausbildung aufnehmen und dennoch viele von ihnen weiterhin auf Arbeitslosengeld II angewiesen sind. Längerer Leistungsbezug betrifft vor allem junge Erwachsene mit geringen Qualifikationen und junge Eltern. Darüber hinaus zeigen sich für den betrachteten Zeitraum keine Hinweise, dass sich die jungen Erwachsenen im Leistungsbezug einrichten.

\section{Introduction}

As in other European welfare states, social policy in Germany focuses on the special needs of young people at risk of poverty and labour market exclusion. However, there has been very little empirical research to assess poverty and benefits claims during the transition to adulthood. The existing literature discusses young adults' financial hardship 
as a transitory experience caused by prolonged education, unemployment or family formation that may be overcome through integration into employment (Aassve et al. 2006). But if young people fail to become established in stable employment they face a high risk of recurrent unemployment and social benefits receipt (Kieselbach 2003). It is suggested that long-term benefits receipt during the vulnerable transition to adulthood is a profoundly negative experience that may limit young adults' further development (France 2008; Furlong 2000). Therefore the concern of the political discourse in Germany is that young people with few prospects may withdraw from the labour market and become resigned to benefits dependency. The underlying assumption of this perception of welfare dependency is that continuing periods on benefits are the consequence of the young beneficiaries' behaviour in response to their opportunities and to their experiences of public support and unemployment (Bane and Ellwood 1994). Hence, further qualification and activation against a familiarisation to benefits receipt for the under- $25 \mathrm{~s}$ became a priority on the agenda of the German benefits system (German Bundestag 2003).

In spite of these political considerations, empirical questions on young beneficiaries' labour market integration are still lacking answers. Therefore, this study addresses the following key issue for young beneficiaries in Germany: which individual characteristics, social and familial compositions influence young adults' chances of coming off benefits through labour market integration? This information is critical for social policy: activation and support would certainly be important for young adults at risk of long-term benefits receipt. Furthermore, it is important to discover whether long periods on benefits and labour market inactivity are caused by individual deficits that can be directly minimised by activation policies, e.g. further training, or are the result of social and familial reasons (Heady 1997).

Therefore this study examines the labour market transitions of young beneficiaries in Germany. It adds the factor of aspects of poverty to the existing empirical literature on school-to-work transitions. Poverty is defined as a household's need to claim social benefits that cover basic living standards. This concept of poverty refers to the current German benefit system that was introduced in 2005 by the socalled "Hartz IV" reforms. The empirical analysis uses a survey sample of 18- to 24-year-old benefits recipients in January 2005 in combination with longitudinal register data for three years. The complex data has the advantage of covering the young beneficiaries' heterogeneous life circumstances, following their benefit and labour market careers for a significant period of time and analysing the influence of personal characteristics and familial situation on the transitions off benefits receipt. These data facilitate a closer focus on young adults than previous studies on benefits receipt were able to.
The article is organised as follows: given the national focus of this study, Sect. 2 provides information on the German benefit system and young beneficiaries in particular, while Sect. 3 summarises the existing empirical evidence about young German benefit recipients and discusses several theoretical aspects. Section 4 provides information about data and methods used for this analysis. The results are presented in Sect. 5. Section 6 gives summary and concluding remarks.

\section{Benefits receipt of young adults in Germany}

Since January 2005, the German social benefit system provides a means-tested basic income subsidy for 15- to 64year-olds who are capable of working and their households, who are on no or inadequate incomes and who are not entitled to further insurance benefits (e.g. unemployment insurance) or after expiry of contribution-based benefits. The benefit combines former unemployment assistance and social assistance. The social benefit (so-called unemployment benefit II, Arbeitslosengeld II) covers adequate housing and subsistence for joint households. ${ }^{1}$ Joint households mainly include the benefits recipient, their partner and their unmarried children (Eichhorst et al. 2008). Under the legal definition of a joint household introduced in 2005, young people over the age of 18 were always treated as a singleperson household even when still living with their parents. $^{2}$ Therefore, the young adults surveyed in this study received benefits with no direct regress to their parents' finances.

Since 2005, the number of 15- to 24-year-olds in receipt of benefits has consistently been around a million (German Federal Employment Agency 2008); this number of young people corresponds approximately 10 per cent of all young Germans in this age group (Popp and Schels 2008). Overall, the population of young beneficiaries in Germany is very heterogeneous; and this group is revisited in the analysis of the study. In January 2005 almost half of beneficiaries aged 18 to 24 were unemployed or participating in training schemes. Furthermore, one tenth of young benefit clients were employees with insufficient earnings who have been additionally supported by the social benefit (Popp et al. 2006). However, benefits receipt by young adults could also be caused by family circumstances if they are living with an unemployed partner or parent (Popp and Schels 2008).

\footnotetext{
${ }^{1}$ At the beginning of 2005 the subsistence rate was $345 €$ for singleperson households with equivalent rates for households with more people; currently the basic subsistence rate is $364 €$.

${ }^{2} \mathrm{~A}$ revision of the benefit law in mid-2006 has included unmarried under 25-year-old children who are living with their parents and on inadequate individual incomes to a joint household with their father or mother.
} 
Therefore more than one third of the young people were in various further activities: they were attending school or vocational training or were on parental leave (Popp et al. 2006). In general, students and trainees in regular education are no longer eligible to claim benefits when receiving training allowances, but there are exceptions depending on the familial situation and the type of school and vocational training.

Beyond the basic income subsidy, active social policy plays a decisive role in the German benefit system through various measures such as counselling, qualification schemes and temporary subsidised job opportunities. Negative and positive incentives for employment are given by financial sanctions and the opportunity to partially keep the benefits and earn extra income from low-paid jobs (Gebauer 2007). Additional support can be offered in case of social problems such as debts, drug abuse or socio-psychological distress, or employment barriers due to caring for children. Overall, activation policies aim at a rapid integration into the labour market as employment is seen as the best way to counteract long-term benefits dependency. And every job-with few exceptions-is regarded as reasonable, meaning that integration into temporary jobs or marginal employment that is not eligible for social insurance contributions is promoted as well (Ludwig-Mayerhofer et al. 2009).

The under-25s are a specific group that is targeted by more robust measures of support and pressure than older benefits clients, as early interventions during the transition to adulthood are considered to be particularly effective (Möhring-Hesse 2006). Young beneficiaries need to receive job or training placement offers or training schemes shortly after starting to claim benefits in order not to become accustomed to labour market inactivity. Furthermore, financial sanctions can be stricter for the under- $25 \mathrm{~s}$ than those addressing older beneficiaries if the young adults are not willing to engage actively in their integration process. Overall, the transitional policies in the benefit system have a strong focus on employment and vocational training to smooth the transition from school to work and concentrate on individual disadvantages due to a lack of qualifications and to social deficits (Walther 2006). But young adults' chances to enter training and employment may be furthermore influenced by the regional labour market conditions with a youth unemployment rate varying between 20 per cent in East Germany and 11 per cent in West Germany in January 2005. Over the surveyed period, the rate of registered youth unemployment in Germany peaked at the beginning of 2005 by almost 15 per cent and declined afterwards to under 10 per cent in 2007 (German Federal Employment Agency 2007).

\section{Empirical and theoretical discourse on benefits receipt during transition to adulthood}

\subsection{Empirical evidence and open questions}

A review of German studies on social assistance dynamics demonstrates that there are very few findings on young adults in benefits receipt and their ways off benefits. The studies compare social assistance receipt among young adults to older recipients. Under-20s live on social assistance for longer than the average population (Buhr 1995); the author relates this finding to difficulties during the school-to-work transition but does not develop this argument. Furthermore, the chances of ending social assistance receipt through full-time employment are better for young adults than for people in their thirties or forties, reflecting the higher general labour market mobility of young people (Gangl 1998; Gebauer 2007). But in a scenario that considers the increase in earnings of employed benefit clients as an alternative exit option, young people are no better off in comparison with older benefits recipients (Gangl 1998). However, it is not discussed further on whether young adults may be at greater risk of lasting benefits receipt during training, by entry into poor-quality work or low starting salaries. Overall, the rare empirical findings cannot constitute evidence if training or job transitions are relevant for young adults to get off benefits nor distinguish individual or situation specific influencing factors during school-to-work transition.

The well-developed research on benefits dynamics among adult recipients emphasises the relevance of labour market transitions to come off benefits. These findings might be relevant for young beneficiaries in particular who have already started their first job or an own family and are therefore in life situations comparable to older benefits clients. For the 18- to 64-year-old beneficiaries, integration into employment is one of the most important ways off benefits, further reasons for leaving benefits receipt are e.g. by the partner's entry into work or by marriage, and administrative reasons (Buhr 1995; Gangl 1998; Gebauer 2007; Gebauer and Vobruba 2003; Gebauer et al. 2003, studies refer to previous social assistance; see Graf 2007 for the first evidence on current social benefit). Studies indicate that leaving benefits receipt by job entry is mainly the matter of individual employment opportunities depending on firstly, individual qualifications, secondly, domestic circumstances and thirdly, demand conditions on the labour market according to the economic cycle (Andreß and Strengmann-Kuhn 1997; Buhr and Weber 1998; Gangl 1998; Gebauer 2007; Gebauer and Vobruba 2003; Hoynes 2000). However, further studies emphasise that the financial situation of the household (Wilde 2003), individual wage expectations and labour supply of benefits recipi- 
ents are significant as well (Schneider and Uhlendorff 2005; Schwarze and Raderschall 2002).

In contrast to the lack of research on young adults' routes off benefits, there exists an extensive literature on school-to-work transitions. Though it has not yet been linked to issues of financial hardship and benefits receipt, the findings are relevant to the study of young beneficiaries indicating that young people at the very start to training or first job might face specific risks of unemployment and financial hardship. Studies demonstrate that young people's transitions into training after general education or work after vocational training are generally connected with a risk of frictional unemployment; but the experience of early long-term unemployment may reduce future job and earning prospects (Dietrich and Kleinert 2005; Lauterbach and Sacher 2001; Scherer 2004a; Schmelzer 2011). Young people with a poor educational background in particular have limited access to training placements or higher education (German Consortium for Coverage of Education 2008; Solga 2008). They are unemployed more frequently and are more likely to enter the labour market via poor-quality work or temporary jobs (Konietzka 2003; McGinnity et al. 2005; Scherer 2001). Moreover, empirical results indicate that young adults with a poor social background in particular are at greater risk to experience early unemployment (McGinnity and Hillmert 2004; Scherer 2004b), which can be explained by an intergenerational transmission of either cultural and social resources which are crucial in the labour market, in particular educational attainment (e.g. Baumert et al. 2006; Becker 2000; Stocké 2007), or employment orientations during familial socialisation.

Summing up so far, it is still an open empirical question if job or training entry is a major way off benefits for young adults. The noted influence of individual characteristics, the familial domain and economic incentives that are relevant for adult benefit clients has to be attested in the context of young beneficiaries' vulnerable passage to adulthood. Benefits receipt may be accompanied by financial insecurity during school-to-work transition. But do low-qualified young people and those with a poor socio-economic background who are in particular risk of longer unemployment also face a certain risk to stay on benefits and develop dependency as suggested by the public discourse described in the introduction? To contribute to the current demand for detailed empirical information on young adults' routes off benefits, the theoretical discussion in the following section has to sort out the factors that are likely to influence the young recipients' labour market chances and behaviour.
3.2 Theoretical perspectives on benefits dependency and labour market processes

\subsubsection{Developing dependence in the benefit system or family context}

The theoretical discourse on benefits dynamics considers both the individuals' labour supply and labour market opportunities as two lines of arguments in the allocation processes on the labour market and the related routes off benefits through job entry (see Gangl 1998). Nevertheless, behavioural models seem to dominate the debate on long-term benefits receipt understanding a low employment participation of benefit recipients in terms of welfare dependence. And this perspective is considered widely in the political and public discourse on young recipients in Germany as mentioned in the introduction.

The rational poverty trap theorem, as well as the psychological concept of learned helplessness, broaches the issue that beneficiaries develop a deficient labour market behaviour in benefits receipt (Bane and Ellwood 1994; Gebauer 2007). As the rational choice argument predicts, benefits recipients are sensitive to financial incentives for employment and therefore trade off the finances in ongoing benefits receipt against taking up employment. It is assumed that young adults experiencing major financial restrictions during benefits receipt should have higher incentives for employment or vocational training in comparison to those living in a comparatively comfortable financial situation despite benefits receipt (Hypothesis 1). The argument is based on the condition that young beneficiaries experience a varying degree of financial pressure as they might have various accesses to for example familial financial support or existing savings. Employment is attractive if people can attain an income above the social benefit level. And therefore Bane and Ellwood (1994: 74) also draw the consequence that beneficiaries have few incentives to mix labour market participation and benefits. The critique on the argument is that employment or training during long periods on benefits should also be attractive for young beneficiaries considering that labour market activity and vocational training increases their future prospects and that the German benefits policy promotes labour market participation by positive and negative incentives (Gebauer and Vobruba 2003; Gebauer 2007). To deal with this issue in the empirical analysis, the exits off benefits by labour market integration are opposed with further labour market transitions into training or jobs that do not lead to economic independence from benefits.

In contrast to the perspective of a rational behaviour in benefits receipt, the concept of learned helplessness as a socio-psychological approach refers to a vicious circle of discouragement in long-term and repeated benefits receipt 
(Leisering and Leibfried 1999). It is assumed that people reduce their job search activities and finally become benefit dependent if they experience recurrent job failure or are not supported properly by the benefit system (Bane and Ellwood 1994). From this perspective, it is expected that young people's incentives to take up employment or training are reduced with repeated unemployment and benefits receipt (Hypothesis 2).

With regard to young adults in receipt of benefits in particular, we have to take into account that growing up in poverty and welfare receipt can affect people's aspirations and resources. At least this is argued by the "culture of poverty" thesis (Lewis 1968; Murray 1984; Wilson 1993), which states that long-term benefits dependency is a perceived phenomenon among a certain sub-population which is carried on by the next generation and which the activation of benefit policies cannot reach. The major argument of the culture of poverty thesis is that young people adopt a low work orientation during socialisation when they experience parental long-term unemployment and benefits receipt in their families (Bane and Ellwood 1994; Gebauer 2007). Young adults with low social background might then show in general a disengaged approach to training and employment as they might have learned to deal with benefits receipt while growing up. According to this view, it is assumed for the empirical analysis that young people with low social background should have few incentives to engage in any employment or training activities and exit benefits dependency (Hypothesis 3)

\subsubsection{Access to training and gainful employment}

In contrast to the different explanations of dependency, diverse labour market theories emphasise that getting off benefits should also be a question of which young beneficiaries have access to either vocational training or employment, and thereby contribute to a household income covering basic living standards. In the context of chronologically institutionalised school-to-work transitions, the theoretical discussion has to consider the heterogeneous life circumstances after finishing general education or vocational training and on the labour market when young beneficiaries gain unequal chances to enter training placements and gainful employment depending on their individual characteristics, family structure (Bane and Ellwood 1994; Gangl 1998) and social background (Dietrich and Abraham 2005).

Given by the institutional settings in the German vocational system, young adults can come off benefits through training entry by access to training allowances that may substitute social benefits depending on type of training and familial circumstances as already mentioned in the previous section. But young beneficiaries who do not receive allowances and whose families cannot meet the basic needs of the household are supported by the benefit system as long they follow education and training anticipating better labour market prospects after graduation; they are currently not available for activation and labour market integration. And participation in regular training is usually binding for several years until graduation ${ }^{3}$ (Blossfeld 1988). These considerations of the institutional settings for young beneficiaries during school-to-work transitions lead to the assumption for the empirical analysis that young adults should be less likely to come off benefits as long they are involved in regular qualification activities (Hypothesis 4).

For those young people who are available for job or training integration, theoretical considerations accentuate the meaning of individual resources for the young beneficiaries' matching processes on the labour market. Thus the opportunities to exit benefits receipt via company-based training (Dietrich and Gerner 2007; Lex 1997) or via gainful employment depend on the employers' demand for productive employees with certain labour market resources; in return, they reward accumulated resources by higher-level job positions (Sørensen and Kalleberg 1994). Relevant individual resources are accentuated by screening and signalling theories (Stiglitz 1975; Spence 1973): based on the productivity assumptions of human capital theory, general qualifications and specific job experience are indispensable (Becker 1962) while times of economic inactivity-especially long-term unemployment-lead to human capital depreciation (Mincer and Ofek 1982) and may go hand in hand with selective recruitment. The assumptions for the empirical analysis are that skilled young adults have improved chances of exiting benefits receipt that can be traced back to privileged recruiting and training prospects and access to advantaged job positions with good pay. In contrast, disadvantaged labour market groups such as the long-term unemployed are expected to have few opportunities to exit benefits receipt through integration into gainful employment (Hypothesis 5 ). Disadvantages on the labour market may either derive in joblessness or integration into poor jobs when people have to mix employment income by further benefits receipt.

Besides individual human capital resources, personal ascriptive characteristics are used by employers to ascribe average statistical labour market information about subgroups to the job candidate by statistical discrimination (Aigner and Cain 1977; Arrow 1975). Relevant subgroups are defined by, for example, gender or migration background (Phelps 1972). Given otherwise equal preconditions, it is assumed that young migrants and women might in particular experience longer benefits receipt than non-migrants or men as

\footnotetext{
${ }^{3}$ In general, non-academic vocational training in companies or vocational schools lasts two or three years and academic education at universities for several years.
} 
they might face additional labour market restrictions by statistical discrimination (Hypothesis 6).

Due to lacking work experience, labour market entrants have available little relevant resources to compete on the labour market but therefore can constitute their parents' resources varying by social origin to gain accesses to job positions (Dietrich and Abraham 2005). Besides the beneficiaries' educational achievements affected by the family's socio-economic status (e.g. Boudon 1974; Erikson and Jonsson 1996), their parents can offer various contacts and information about gainful labour market positions depending on their own labour market position. In particular, children of low-qualified parents in low-level work or unemployment have limited information and contacts for high-level employment (Solga 2005). In contrast to the approach of a culture of poverty assuming a general low employment orientation among young beneficiaries with low social background, the resources approach expects that young people with low social background tend to participate in the labour market but face barriers to gainful job positions as they can mobilise less relevant resources compared with peers from high social backgrounds. Thus one can expect for the empirical analysis that greater chances of moving off benefits through labour market integration should be observable for young people from higher social background while young beneficiaries from low social background are more likely to enter jobs with an income level under the social benefits level. Differences in the routes off benefits by the socio-economic status should hold by given equal qualifications (Hypothesis 7)

Finally, individual opportunities and choices to take up employment depend on the family composition. It is considered that young parents trade off the rewards of and resources for employment against family commitments to assure the welfare of their family. Employment decisions depend on the job and wage prospects of the employable household members (Becker 1976; Leisering and Voges 1992) as well as on the availability of child care facilities (Büchel and Spieß 2002) and conditions in the German benefit system. Beneficiaries who attend to their own children under the age of three ${ }^{4}$ are not involved in activation schemes. Overall, parents caring for their children have limited job alternatives, especially for full-time employment. This certainly applies to lone parents who cannot arrange child-caring commitments with a partner. Thus, it is furthermore assumed for the empirical analysis that individual choices and opportunities for employment and training vary according to household composition; young parents, in particular lone parents, have fewer chances to leave benefits receipt via labour market integration (Hypothesis 8).

\footnotetext{
${ }^{4}$ Or who have caring responsibilities for family members.
}

\section{Data and methods}

The empirical analysis is based on the survey 'Life Circumstances and Social Security 2005 (LSS05)' from the Institute for Employment Research in Germany. The survey uses a sample of beneficiaries, drawn from the records of the German Federal Employment Agency in January 2005 (Meßmann et al. 2008). The survey data were combined with longitudinal register data from the Federal Employment Agency up to December 2007 providing information about labour market and training participation and benefits receipt. The following analyses refer to 1061 benefits episodes in the period of observation of 674 18- to 24-yearolds who started to claim benefits in January 2005 but who had been claiming neither unemployment assistance nor social assistance in December 2004. This restriction avoids left censoring.

In the survey, people were asked at the end of 2005 for their current material situation and household composition and their situation in December 2004, and for their social background as well as educational and employment careers up to 2005. The register data give information about periods of benefits receipt and registered unemployment, employment liable for social insurance and company-based training. Activities like self-employment, shadow employment, studies at university or vocational schools, or parenthood cannot be observed in the register data. Therefore the existing career information of the survey was used to fill in missing information. Data are organised in person months.

The major interest of the analysis is on the process of getting off social benefits by the young adults' transitions into job or training. Labour market integration includes an entry into a new job or vocational training in firms. Considering that job or training entries can either lead to an increase in the household income to allow independence from social benefits or not, the analysis distinguishes between young adults who exit from benefits by labour market integration (A) or realise a partial exit from benefits by labour market integration (B) as they enter job or training positions where the earnings do not cover the needs of the household. The latter leads to reduced benefits receipt as the amount of the subsidy decreases with an additional income but benefit episodes last on. Furthermore, it is taken into account that trainees or employed beneficiaries on low incomes in the sample can get off benefits by transitions into a better labour market position maintaining sufficient earnings e.g. by job replacements or an increasing income (e.g. Gangl 1998).

The analysis of the young beneficiaries' exit routes off benefits receipt is conducted in two steps: In the first step, descriptive statistics explore the relevance of labour market integration for getting off benefits in contrast to other reasons not linked to individual labour market transitions such as family events, e.g. (re-)employment of the parents 
or partner, marriage or entry into further schooling or universities like previous empirical findings have shown (e.g. Buhr 1995). These various reasons are combined in a singular category for analysis as they cannot be differentiated in the data that were used. Furthermore, young adults may stay on unimproved benefits receipt if they cannot realise any job entry nor exit from social benefits, for example in the case of long-term unemployment, parental leave or ongoing education. ${ }^{5}$

In the second step, the analysis measures the explanatory factors on the process of getting off social benefits through the young adults' entries into job or training. The analysis differentiates between exits from benefits by labour market integration (A) and partial exits by labour market integration (B). Hazard rates into the two destination states (competing risks) are jointly estimated by a discrete time model for multiple events (see Steele et al. 1996, 2004). The model allows for correlation across job and training transitions leading either to independence from benefits or not, in shared unmeasured risk factors (see e.g. Hill et al. 1993). The overall hazard rate for both destination states is defined as the conditional probability that the young people enter employment or training in a certain time interval $t$ given lasting benefits receipt up to at least time $t$ (van den Berg 2001). The model considers multiple episodes including all observed episodes in benefits receipt in the period of observation as well as further job or training transitions or exits off benefits after partial exits by labour market integration. Each episode in benefits receipt and split episode after a partial exit starts with time equal to 0 . Episodes following a partial exit are marked by a dummy indicator. Spells are right-censored if young people are not involved in jobs or vocational training in benefits receipt and have left benefits receipt for other reasons or are still living on benefits at the end of December 2007.

Given the hierarchical structure of the discrete-time data where several episodes $j(j=1, \ldots, n)$ are nested by individuals $i$, the hazard rates $h$ at a given time interval $t$ for both destination states $r$ ( $r=A, B$ or $r=0$ for right-censored intervals) can be modelled by random effect logits. ${ }^{6}$

$\log \left(\frac{h_{i j}^{(r)}(t)}{h_{i j}^{(0)}(t)}\right)=\alpha^{(r)}(t)+\beta^{(r)} x_{i j}^{(r)}+u_{i}^{(r)}$

The effect of duration is represented by $\alpha^{(r)}(t)$ and is assumed piecewise constant. The variation of the destination-

\footnotetext{
${ }^{5}$ However, there is only a small percentage of surveyed young adults in permanent unemployment ( 4.5 per cent), vocational training ( 1.0 per cent) or on parental leave (1.3 per cent) over the period of observation of three years.

${ }^{6} \mathrm{~A}$ likelihood ratio test shows a significant improvement of the model with random effects in contrast to a simple discrete event history analysis.
}

specific baseline hazard rates is estimated by a vector of individual time-constant and time-variable covariates $x_{i j}^{(r)}$. Destination-specific error terms $u_{i}^{(r)}$ represent the joint influence of the unmeasured risk factors. The random effects are assumed to follow a multivariate normal distribution, with covariance matrix $\Omega$; a nonzero correlation between the destination-specific random effects allows for shared unobserved risk factors.

\subsection{Covariates and descriptive statistics}

The model includes several covariates as described in Table 1 . Unless otherwise noted, the following figures refer to January 2005.

- The financial situation is measured by the household's net income in the survey weighted by the new OECD equivalent scale. The analysis estimates periodic effects of the equivalent household income as the household information given refers to two points in time, December 2004 and November 2005. The average equivalent income over the period of observation was about 1030 Euros.

- Previous benefits receipt is measured by the accumulated number of episodes in benefits receipt over the period of observation. Moreover, benefits receipt prior to 2005 is considered by dummy variables: 6 per cent of the 18- to 24-year-olds have already been in receipt of unemployment assistance before 2005. Further information on receipt of previous social assistance is just given in the survey data for 2004. Figures show that 8 per cent of the young adults claimed social assistance in 2004.

- The social background is measured by, first, the highest educational level of the father or mother considering the fact that one parent has at least a lower secondary school certificate. This is true for 82 per cent of the young beneficiaries surveyed. Second, the highest employment position of the father or mother when the respondent was aged 15 is considered distinguishing between low-qualified employment ( 22 per cent), qualified employment (48 per cent) and unemployment/non-employment (18 per cent). Some young beneficiaries, about 10 per cent, could not give any information on the parents' status.

- Human capital is first measured by schooling. For students, the educational qualification measures the degree they achieve. Forty-five per cent have no or a lower secondary school certificate, 33 per cent have or achieve a secondary school graduation and 22 per cent a university entrance degree. Second, a dummy indicator for vocational qualification illustrates that in January 2005 about 30 per cent have graduated vocational training. Schooling as well as vocational qualifications are time-variable covariates as the young adults may graduate during the period of observation. 
Table 1 Descriptive statistics of the covariates (\%, mean (standard deviation))

\begin{tabular}{|c|c|c|}
\hline & January 2005 & $\begin{array}{l}\text { Person months } \\
\text { in period of } \\
\text { observation }\end{array}$ \\
\hline Equivalent household net income (in $€$ ) & $1225.2(718.02)$ & $1032.1(647.1)$ \\
\hline Social assistance receipt in 2004 & 8.1 & 7.8 \\
\hline Unemployment assistance receipt before 2005 & 5.9 & 6.2 \\
\hline Social benefits episodes & - & $0.2(0.52)$ \\
\hline \multicolumn{3}{|l|}{ Highest qualifications of the parents } \\
\hline No information & 11.0 & 11.1 \\
\hline No school certificate & 7.1 & 7.7 \\
\hline At least lower secondary school certificate & 81.9 & 81.2 \\
\hline \multicolumn{3}{|c|}{ Highest employment status of the parents (at respondents' age of 15) } \\
\hline No information & 13.2 & 13.7 \\
\hline Low-qualified employment & 21.7 & 22.2 \\
\hline Qualified employment & 47.7 & 45.4 \\
\hline Unemployed, not employed & 17.4 & 18.7 \\
\hline \multicolumn{3}{|l|}{ Schooling } \\
\hline No/lower secondary school certificate & 45.3 & 48.9 \\
\hline Secondary school certificate & 32.9 & 33.4 \\
\hline University entrance diploma & 21.8 & 17.7 \\
\hline Vocational degree & 30.6 & 31.5 \\
\hline Previous employment episodes & $2.3(2.71)$ & $2.3(2.86)$ \\
\hline Previous unemployment episodes & $1.3(1.56)$ & $1.7(1.76)$ \\
\hline \multicolumn{3}{|l|}{ Labour market status } \\
\hline Employed & 9.3 & 9.2 \\
\hline Short-term unemployed, $\leq 12$ months & 35.5 & 31.2 \\
\hline Long-term unemployed, 13 months and more & 1.9 & 14.7 \\
\hline In education & 37.7 & 25.7 \\
\hline On parental leave & 5.8 & 9.6 \\
\hline Other activities & 9.8 & 9.6 \\
\hline \multicolumn{3}{|l|}{ Household composition } \\
\hline Single & 20.6 & 23.1 \\
\hline With partner, no children & 9.5 & 8.8 \\
\hline Single parent & 4.9 & 8.8 \\
\hline With partner and children & 11.1 & 14.9 \\
\hline With parents & 53.9 & 44.4 \\
\hline Female & 52.1 & 52.8 \\
\hline Migration background & 41.4 & 41.1 \\
\hline Age & $20.1(1.80)$ & $21.4(2.06)$ \\
\hline Regional youth unemployment rate & $13.7(3.6)$ & $12.6(3.59)$ \\
\hline$n /$ person months & 674 & 15959 \\
\hline
\end{tabular}

Source: LSS 05, register data; author's calculations

- The employment biography is described by time-variable measures for the accumulated number of employment episodes and unemployment episodes up to the observed point of time and their squared values to control for nonlinear effects. The indicators count on for further em- ployment experiences during the period of observation. On average, the young beneficiaries have experienced 2.3 employment episodes and 1.3 unemployment spells until January 2005. The number of employment episodes and unemployment episodes can be interpreted as a signal 
for the young adults' labour market establishment. While low numbers of employment episodes are a sign that the young adults have already gained first experience on the labour market, a rising number of employment and unemployment spells indicate an early discontinuous labour market career.

- The employment status in the previous month captures the individuals' position during school-to-work transition. Young adults might be in employment (9 per cent) or unemployment including participation in active labour market schemes (37 per cent). The latter distinguishes between unemployment up to 12 months and more than 12 months to control for the assumed negative effects of long-term unemployment. ${ }^{7}$ Furthermore, the young people may be in education (38 per cent) including mainstream education and general vocational training assuming that both statuses are connected with unavailability for labour market integration until graduation. Finally young people may be on parental leave (6 per cent) or in other activities where there is no further information in the data (10 per cent).

- The household composition distinguishes between young singles ( 21 per cent in January 2005), living with a partner (10 per cent), living with a partner and children (11 per cent), lone parents (5 per cent) and young people living with their parents (54 per cent) and considers changes over the period of observation.

- Furthermore, the analysis takes into account gender (52 per cent females) and migration background for young people, who were not born in Germany or whose parents have migrated to Germany (41 per cent). The model is also controlled for age and the regional youth unemployment rate and seasonal effects.

The descriptive statistics illustrate that the surveyed 18- to 24-year-old beneficiaries are a heterogeneous social group with unequal resources and living in diverse life situation that are assumed to influence the routes off benefits through labour market integration. However, the young adults' living conditions vary by their social conditions in the household and family as the correlation matrix in Table 2 shows for selected covariates. ${ }^{8}$ So, the figures indicate that the young beneficiaries' financial resources and qualifications are significantly associated with their parents' socio-economic background. Growing up with parents with no school certificate or parental unemployment is negatively

\footnotetext{
${ }^{7}$ The young beneficiaries' transitions from short-term to long-term unemployment do not correspond with the estimated piecewise constant effects. Benefits receipt is not restricted to unemployment (see Sect. 2), also meaning that the observed entry dates into unemployment for the young people vary individually.

${ }^{8}$ The complete correlation table is available from the author on request.
}

correlated with the young adults' equivalent household income and with schooling. Furthermore, a poor financial situation is associated with previous receipt of social assistance and unemployment assistance indicating lasting economic restrictions. However, the correlation coefficients also show that the equivalent household income is higher for young beneficiaries living together with their parents and low for singles. The connection illustrates that the young adults' financial resources are also influenced by dissolution from the parents' household and starting an own household (Aassve et al. 2006).

\section{Results}

\subsection{Exits from benefits receipt and labour market integration}

Descriptive statistics for the young adults' exits off benefits receipt are presented in Table 3. The results given by the distribution of the marginal total per cent show first that 24 per cent of the observed 1061 benefits episodes were ended by the young beneficiaries' integration into employment or vocational training in firms. But in most cases, 49 per cent, the young beneficiaries ended their benefits episodes for other reasons. Twenty-eight per cent of the benefits episodes are censored as they were still lasting in December 2007. Overall, about 22 per cent of the surveyed 18- to 24-year-old beneficiaries who started to claim benefits in 2005 had been in permanent benefits claims for three years until the end of the period of observation (not shown in the table).

Though labour market integration is not the main way off benefits, this finding must not be interpreted as though young benefit clients are detached from employment or training. The distribution of the row per cent in Table 3 shows that in 49 per cent of all surveyed benefits episodes, the young beneficiaries at least realised a partial exit by entering a job or training position. However, their income is under the socio-economic existence minimum for the household so that they stay on benefits receipt. Hence, exiting benefits receipt can be a process of several labour market transitions until young adults achieve a final exit: in 54 per cent of the benefits episodes that ended by other reasons and in 45 per cent of the censored episodes, the young beneficiaries were able to reduce their benefits receipt via labour market integration in the months before. The findings clearly show that entries into jobs or training with further benefits receipt are a relevant experience among young social beneficiaries. The figures indicate that many young beneficiaries accept to mix benefits receipt and employment or training and therefore show a relative high labour market participation even in benefits receipt. 


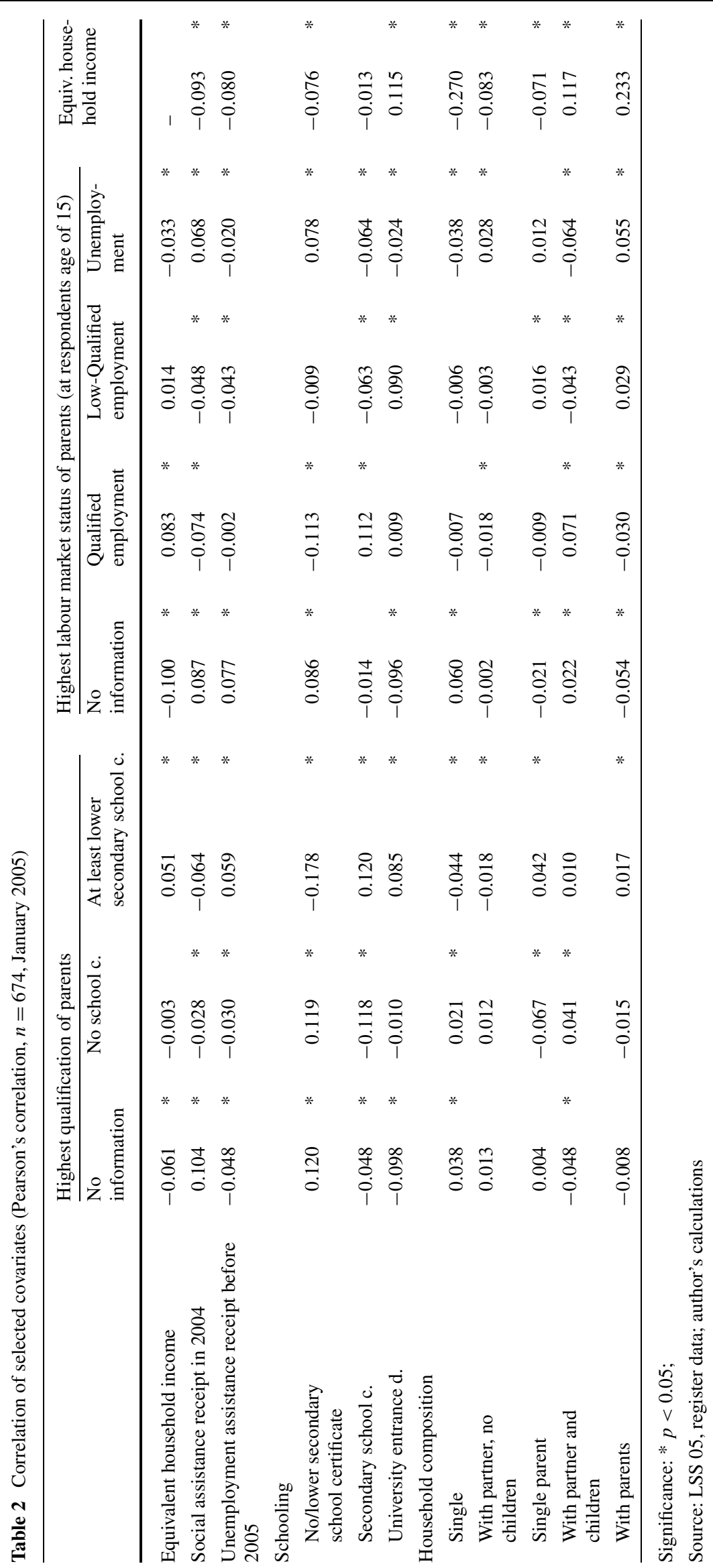


Table 3 Routes off benefits receipt in 2007 of 18- to 24-year-old benefits recipients of 2005 (weighted cell per cent, row per cent, 1061 episodes)

Source: LSS 05, register data; author's calculations

Table 4 Types of job or training entry in 2007 of 18 - to 24-year-old benefits recipients of 2005 (weighted per cent)

Source: LSS 05, register data; author's calculations

\begin{tabular}{|c|c|c|c|}
\hline \multirow[t]{2}{*}{$\begin{array}{l}\text { Episodes in } \\
\text { benefits receipt }\end{array}$} & \multicolumn{2}{|c|}{$\begin{array}{l}\text { Partial exits by individuals' } \\
\text { labour market integration }\end{array}$} & \multirow[t]{2}{*}{ Total } \\
\hline & No & $\overline{\text { Yes }}$ & \\
\hline \multirow{2}{*}{$\begin{array}{l}\text { Exits by individuals' labour } \\
\text { market integration }\end{array}$} & 13.7 & 10.0 & 23.7 \\
\hline & 57.7 & 42.3 & 100.0 \\
\hline \multirow[t]{2}{*}{ Exits by other reasons } & 22.2 & 26.5 & 48.7 \\
\hline & 45.6 & 54.4 & 100.0 \\
\hline \multirow{2}{*}{$\begin{array}{l}\text { Censored episodes, lasting } \\
\text { until December } 2007\end{array}$} & 15.3 & 12.4 & 27.6 \\
\hline & 55.3 & 44.7 & 100.0 \\
\hline Total & 51.2 & 48.9 & 100.0 \\
\hline
\end{tabular}

Exits off benefits receipt

by labour market integration

(A)

\begin{tabular}{lrrr}
\hline Regular employment & 51.6 & 28.9 & 37.5 \\
Training in firms & 27.2 & 29.2 & 28.5 \\
Marginal employment & 12.2 & 32.0 & 24.4 \\
Improved job position & 9.1 & 9.9 & 9.6 \\
Total & 100.0 & 100.0 & 100.0 \\
$n$ & 197 & 327 & 483 \\
\hline
\end{tabular}

Partial exits off benefits receipt by labour market integration

(B)
Whether an entry into a new job or training leads to an exit from benefits receipt may be dependent on job characteristics. Regular employment is the most common way off benefits (Table 4): 52 per cent of all exits from benefits claims via labour market integration were realised by young people who took up a regular job. By comparison, integration into vocational training in firms and marginal employment are the most frequent events among cases of reduced benefits receipt. Nevertheless, reduced benefits receipt could also be observed for young adults taking up regular employment and marginal employment can lead to financial independence.

\subsection{Influencing factors of exiting benefits receipt by employment integration}

Table 5 presents the estimated individual-specific hazards of the piecewise constant model with dependent competing risks: ${ }^{9}$ exit from benefits receipt via integration into employment or vocational training in firms (A) and partial exit via labour market integration (B). The effects of the covariates on the hazard rate are presented as hazard ratios. In the used

\footnotetext{
${ }^{9}$ The modelling of the shared unmeasured risk factors for both transition states fits a low and insignificant covariance of the hazards of the labour market transitions of young beneficiaries.
}

model, the covariates can be interpreted as both the effects on the speed of the transition process off benefits receipt and the effect on the probability that the young adults realise an event in the period of observation (Bernardi 2001). The hazard ratio for continuous covariates shows the proportional change in the hazard following a unit change. A figure higher than 1 (smaller than 1) indicates that the young beneficiaries' transition into a destination state increases (is reduced) holding the other characteristics constant. For categorical covariates, the hazard ratio shows proportional differences in comparison to the reference group. Values higher (smaller) than 1 indicate a higher (lesser) transition into the destination state in comparison to the reference group $(r f)$.

A main assumption was that young beneficiaries may develop benefits dependency by individual experiences of poverty. However, the analysis shows no significant effects that the equivalent household income influences the beneficiaries' labour market transitions. There is no evidence that the young people routes off benefits receipt by labour market integration are dependent on the financial resources in the household. The finding is not in line with the argument of rational labour market behaviour assuming that the financial incentives for taking up employment are reduced when the young beneficiaries' household has a higher equivalent income which can be interpreted as an indicator for the financial pressure in the household (Hypothesis 1). A further hy- 
Table 5 Determinants of the routes off social benefits receipt through job or training entry of 18- to 24-year-old benefits recipients of 2005 (hazard ratios $\exp (ß))$

\begin{tabular}{|c|c|c|c|c|c|c|}
\hline \multirow[t]{3}{*}{ Covariates } & \multicolumn{6}{|l|}{ Model } \\
\hline & \multicolumn{3}{|c|}{$\begin{array}{l}\text { Exit via labour market inte- } \\
\text { gration (A) }\end{array}$} & \multicolumn{3}{|c|}{$\begin{array}{l}\text { Partial exit via labour market inte- } \\
\text { gration (B) }\end{array}$} \\
\hline & $\mathrm{Hr}$ & Sig. & S.E. & $\mathrm{Hr}$ & Sig. & S.E. \\
\hline \multicolumn{7}{|l|}{ Equivalent household income (/100). periodic effects } \\
\hline Income situation of Dec 04 in Jan 05-Oct 05 & 0.988 & & 0.008 & 0.995 & & 0.006 \\
\hline Income situation of Nov 05 in Nov 05-Dec 06 & 1.012 & & 0.013 & 1.013 & & 0.010 \\
\hline Income situation of Nov 05 in 2007 & 1.000 & & 0.017 & 1.009 & & 0.012 \\
\hline Social assistance receipt in $2004(r f=n o)$ & 0.837 & & 0.313 & 1.206 & & 0.197 \\
\hline Unemployment assistance receipt before $2005(r f=n o)$ & 0.613 & & 0.360 & 0.699 & & 0.257 \\
\hline Previous episodes in social benefits receipt & 0.767 & & 0.177 & 1.200 & & 0.115 \\
\hline \multicolumn{7}{|c|}{ Highest qualification of parents ( $r f=$ lower secondary school certificate or higher $)$} \\
\hline No information & 1.063 & & 0.256 & 1.098 & & 0.180 \\
\hline No school certificate & 0.514 & + & 0.402 & 0.988 & & 0.237 \\
\hline \multicolumn{7}{|c|}{ Highest labour market status of parents, at respondent's age of 15 ( $r f=$ qualified employment $)$} \\
\hline No information & 0.627 & & 0.276 & 0.888 & & 0.179 \\
\hline Low-qualified employment & 0.846 & & 0.217 & 0.858 & & 0.157 \\
\hline Unemployed, not employed & 1.073 & & 0.248 & 0.861 & & 0.176 \\
\hline \multicolumn{7}{|l|}{ Schooling $(r f=$ no/lower secondary school certificate) } \\
\hline Secondary school certificate & 1.158 & & 0.209 & 0.932 & & 0.146 \\
\hline University entrance diploma & 1.784 & * & 0.268 & 1.140 & & 0.201 \\
\hline Vocational degree $(r f=$ no degree $)$ & 2.288 & $* * *$ & 0.212 & 1.482 & $* *$ & 0.139 \\
\hline \multicolumn{7}{|l|}{ Employment career } \\
\hline Previous employment episodes & 1.610 & $* * *$ & 0.080 & 1.304 & $* * *$ & 0.048 \\
\hline$(\text { Previous employment episodes) })^{2}$ & 0.982 & $* * *$ & 0.005 & 0.992 & $*$ & 0.003 \\
\hline Previous unemployment episodes & 0.711 & * & 0.137 & 0.949 & & 0.099 \\
\hline$(\text { Previous unemployment episodes })^{2}$ & 1.032 & * & 0.016 & 1.001 & & 0.012 \\
\hline \multicolumn{7}{|l|}{ Employment status. one month lag. (ref: employed) } \\
\hline Short-term unemployed. $\leq 12$ months & 2.435 & $* *$ & 0.265 & 2.790 & $* * *$ & 0.214 \\
\hline Long-term unemployed. 13 months and more & 1.864 & + & 0.350 & 4.258 & $* * *$ & 0.257 \\
\hline In education & 0.440 & $*$ & 0.375 & 1.095 & & 0.262 \\
\hline On parental leave & 1.020 & & 0.528 & 1.397 & & 0.329 \\
\hline Other activities & 0.977 & & 0.388 & 2.265 & $* *$ & 0.284 \\
\hline Previous partial exit $(r f=$ none $)$ & 0.871 & & 0.196 & 1.861 & $* * *$ & 0.138 \\
\hline \multicolumn{7}{|l|}{ Household composition $(r f=$ single $)$} \\
\hline With partner, no children & 0.910 & & 0.277 & 0.983 & & 0.208 \\
\hline Single parent & 0.306 & $*$ & 0.472 & 1.021 & & 0.260 \\
\hline With partner and children & 0.425 & $* *$ & 0.326 & 1.252 & & 0.200 \\
\hline With parents & 1.333 & & 0.214 & 0.931 & & 0.164 \\
\hline \multicolumn{7}{|l|}{ Socio demographics } \\
\hline Female $(r f=$ male $)$ & 0.749 & & 0.177 & 1.028 & & 0.127 \\
\hline Background of migration $(r f=n o)$ & 0.741 & & 0.192 & 0.882 & & 0.133 \\
\hline \multicolumn{7}{|l|}{ Controls } \\
\hline Age & 1.088 & & 0.061 & 0.914 & $*$ & 0.043 \\
\hline Regional youth unemployment rate & 0.941 & $*$ & 0.026 & 0.994 & & 0.018 \\
\hline Events & & 197 & & & 327 & \\
\hline Persons/episodes/person months & \multicolumn{6}{|c|}{$674 / 1061 / 15959$} \\
\hline Log likelihood & \multicolumn{6}{|c|}{-2401.4207} \\
\hline Cov (Corr) & \multicolumn{6}{|c|}{$0.138(0.999)$} \\
\hline
\end{tabular}

Models controlled for piecewise constant periodic effects and seasonal effects but not reported

Source: LSS 05, register data; author's calculations

$\mathrm{Rf}=$ reference category; $\mathrm{Hr}=$ hazard ratio; sig. = Significance; S.E. = standard error

Significance: $+p \leq 0.1 ; * p<0.05 ; * * p<0.01 ; * * *<<0.001$. 
pothesis was that long-term benefits receipt may be the consequence of discouraging experiences within the labour market and recurrent benefits receipt (Hypothesis 2). Following this perspective, there is no empirical evidence for processes of learned helplessness in repeated benefits receipt as neither social assistance nor unemployment assistance receipt prior to 2005 nor repeated receipt of social benefits since 2005 reduces young people's chances of entering the labour market. But there is evidence that emerging long-term benefits receipt among young adults is a question of previous unemployment episodes that indicated careers in repeated unemployment. In line of the argumentation, the slowing effect of previous unemployment spells on the exits off benefits by labour market integration may indicate that young adults withdraw from the labour market and resign themselves to benefits receipt to avoid further disappointment or that employers perceive unemployment as a negative signal. However, the analysis is not able to give clear evidence as to whether exclusion by employers during recruitment processes or experiences of disappointment are more important.

Furthermore, the results suggest that it is more difficult to leave benefits receipt via labour market integration for the 18- to 24-year-old beneficiaries with a poorly qualified mother or father than for young people with parents with school graduation given equal qualifications of the young beneficiaries. ${ }^{10}$ However, the effect is significant on a 10 per cent level. But there is no effect of the parental social background on partial exits off benefits receipt; the young beneficiaries' labour market participation in jobs or training positions under the socio-economic existence minimum is not depending on the social background. Overall, the young beneficiaries with a relative higher social background are more likely to gain access to gainful training or employment positions. In light of Hypothesis 7, an explanation could be that young adults growing up in families with a poor socioeconomic status have accumulated fewer resources besides qualifications that are crucial on the labour market. Furthermore and in contradiction to the assumptions according to the cultural hypothesis (Hypothesis 3), young beneficiaries with a poor social background do not accept transitions into job or training positions below the social benefit threshold to a lesser extent than young adults with qualified parents. There is no evidence for the interpretation that young people with low-qualified parents are a subgroup that has adopted a low work orientation.

In line with Hypothesis 5 and research on school-to-work transitions, qualifications and previous labour market experiences are strong predictors for the 18- to 24-year-old

\footnotetext{
${ }^{10}$ Additionally, population-average mean hazards were estimated for the time-constant categories to approve the results of the individualspecific random effect model: the mean hazard for the transition off benefits by labour market integration of young adults whose mother or father have a lower secondary school graduation or lower is 0.541 in reference to young beneficiaries with higher educated parents.
}

beneficiaries' labour market chances. But in particular, the probability that the surveyed young adults' enter gainful job or training positions is connected with high general and vocational qualifications. Furthermore, the relevance of the young adults' current employment status during school-towork transition is stressed significantly. There is a higher probability to get off benefits receipt by integration into a new job or training position when the young beneficiaries are currently unemployed than when they are already employed - but in jobs that do not provide sufficient earnings for the joint household. This is particularly true in short-term unemployment while there is a lower transition probability after one year in unemployment. In comparison, young people have significantly fewer chances to exit benefits claims by labour market integration as long they follow mainstream education or vocational training as assumed in Hypothesis 4. There are no significant effects from parenthood. These findings illustrate the different institutional settings for young beneficiaries during the transition to adulthood. Unemployed young beneficiaries are clearly supported by activation policies to participate in training or the labour market while long periods spent on benefits by young people are connected with regular education or vocational training until graduation. Furthermore, the probability to get off benefits by labour market integration is lower for young adults living in a region with high youth unemployment; the probability to enter job or training positions in lasting benefits receipt declines with rising age.

There is a strong effect that young beneficiaries in longterm unemployment realise a partial exit and reduce benefits receipt via labour market integration. According to Hypothesis 5 that young unemployed experience reduced opportunities to exit benefits receipt through labour market integration, the results can be interpreted as if young long-term unemployed switch to low-paid jobs when they are filtered out of gainful job positions by employers during recruitment processes and only have access to marginal job positions. This interpretation is supported by the descriptive finding that partial exits are mostly due to integration into marginal employment (see previous section). As a consequence, some young beneficiaries seem to experience employment careers on state support. A previous partial exit via labour market integration has a positive effect on the probability that the young people experience further partial exits, but it does not significantly promote a final exit via labour market integration. The probability of exiting benefits receipt by labour market integration is reduced when the young beneficiaries have accumulated a rising number of employment episodes and unemployment experience which are indicators for a discontinuous employment career. Young people may be trapped in a series of temporary jobs and recurrent unemployment that limits their employment and financial perspectives in the long run as already shown by previous empirical literature. 
Furthermore, the assumption that young women and migrants have significant poor labour market prospects and chances of exiting benefits receipt cannot be confirmed. Controlling for otherwise equal conditions, the findings report that among the surveyed sub-population of young adults, women do not take up employment or training more slowly than men; the migrants' chances to get off benefits via labour market integration are not significantly lower than for non-migrants. However, research has shown that migrants and women are certain risk groups for benefits receipt (Gangl 1998; Garcia and Kazepov 2002; Strengmann-Kuhn 2007), and in particular, young migrants are overrepresented among young beneficiaries in Germany (Achatz et al. 2007; Popp and Schels 2008). But further risks of lasting benefits receipt for young migrants do not apply to exits from benefits via labour market integration like it would be assumed by statistical discrimination (Hypothesis 6 ).

In line with Hypothesis 8, the probability to get off benefit claims by labour market integration depends on the family context. When young people are living in households with children, they have significant fewer chances of exiting benefits receipt through employment than young adults without children. The result supports that young adults with children have to meet higher financial requirements than singles, as well as that the employment prospects of parents caring for their children and especially lone parents are limited (e.g. Gebauer 2007; Klett-Davies 2007; Lietzmann 2009; Strengmann-Kuhn 2001). Moreover, the findings illustrate that the probability of staying on benefits receipt does not only correspond with the individual opportunities in the transition to vocational training or employment but also with the process of starting a family.

\section{Summary and conclusions}

This study examined the exits from benefits receipt via labour market integration of 18- to 24-year-old beneficiaries of January 2005 in Germany. It addressed the questions if young people are at certain risk to develop dependency in benefits receipt or by their social origin or if the chances to get off benefits through training or job entry are influenced by individual labour market opportunities.

Considering several empirical indicators, there is no evidence for young people resigning themselves to benefits receipt as predicted by theoretical arguments of welfare dependency. First, the descriptive analysis thus illustrates that although labour market integration is not the most frequent route off benefits receipt for young adults, many of the young beneficiaries surveyed reduce at least benefits receipt through entering employment or vocational training. Labour market integration of young benefits recipients does not necessarily correspond with exiting benefits receipt as in many cases the earnings do not cover the needs of the household. The result contradicts the prediction of the rational choice argument that the young beneficiaries' financial incentives to mix employment, respectively training participation and benefits receipt, are low. Second, the results of the multivariate analysis indicate, that ongoing benefits receipt in the period of observation is not a matter of a culture of poverty among young people with a low social background or a financial utilisation of the benefits or withdrawal in repeated benefits receipt. But findings suggest that some young beneficiaries in recurrent unemployment seem to withdraw from the labour market while others seem to continue trying to find a job in long-term unemployment. The interpretation of the findings is difficult as the study cannot clearly differentiate if the results are the consequence of discouraging experiences or of sorting processes on the labour market when lasting unemployment may be perceived as a negative signal for the young adults' employment orientation. An alternative explanation may be that young people in discontinuous employment careers are a selective subgroup that is characterised by low self-esteem, work motivation or work performance (Hammer 1996).

The results of the analysis support the hypothesis that longer benefits receipt among young adults is mainly a matter of restricted labour market and income opportunities which are structured by the institutional settings in the status passage to employment. The results are in line with former findings about German adult social assistance clients (Buhr 1995; Gangl 1998; Gebauer et al. 2003; Gebauer 2007). Looking at the different influencing factors, it turns out that longer benefits receipt among young adults has two major reasons. First, findings attest that low-qualified young people and those with discontinuous school-to-work transitions who are well-known risk groups on the labour market are at risk of longer benefits receipt. And there is a hint that young beneficiaries with low social background in particular have disadvantaged chances to reach gainful job or training positions to get off benefits. Second, young parents-and especially lone parents-face major difficulties in earning sufficient money for their family, meaning that individual labour market risks might accumulate during the status passage to adulthood with further uncertainties due to family formation.

In the light of the findings that young beneficiaries are not generally at risk to develop dependency in the limited period of observation but process the experience of repeated and long-term unemployment in different ways, it keeps an open empirical question under which conditions young people's failure in training or job entry affects their labour supply and further transitions to financial independence. The study cannot give evidence in particular to whether recipients develop dependence in the very long run if they fail to establish in stable employment as young adults. Further 
theoretical discussion and research on benefits receipt will have to address the issue of how individual orientations develop and affect transitions to financial independence. Qualitative case studies have already shown that the risk of marginalisation among young beneficiaries in insecure school-to-work transitions is dependent on their interpretation of the given biographical context and their resources for coping (Drilling 2004; Leisering and Leibfried 1999; Ludwig 1996). Subsequently, following the perspective that financial hardship might not only be a transitory experience, empirical efforts will have to investigate in the processes of poverty and benefits receipt during the status passage from youth to mid-adulthood based on further longitudinal data.

According to the results of the study, the general perception within the public and political discussion in Germany that young beneficiaries show a low degree of labour market orientation is challenged and emphasise is given to the labour market and training perspectives to disadvantaged young adults. The findings support further policy investigations into employment barriers such as a lack of general and vocational education and a lack of childcare options. Furthermore, the findings are of interest for critical transitional policies in the benefit system emphasising awareness of the special needs during the status passage to adulthood as benefits receipt is not only to be a matter of disadvantages on the labour market but also a risk when starting a family. According to the general discussion on activating young people (France 2008; Walther 2006), social policies have to suggest ideas about how best to avoid discouraging unemployment experiences or at least cushion their impact. Nevertheless, the results indicate more generally that financial hardship among young adults may not only be a transitory experience until they succeed to transit into employment. Financial restrictions might be prolonged if they fail to establish in stable gainful job or training positions and enter jobs with an income below the social benefit level.

\section{Executive summary}

Since the extensive labour market and social security reforms in Germany in January 2005, the life circumstances of youths and young adults in receipt of social benefits are one major focus in the public and political discussion. The discourse is partly driven by prejudices on the young people's willingness to take up vocational training or employment to overcome benefits receipt. The perception is that young people with few prospects may withdraw from the labour market and become resigned to benefits dependency. Hence, stronger activation against a familiarisation to benefits receipt for the under-25s in comparison to older beneficiaries is a priority on the agenda of the German benefits system. Against this background, the study deals with the issue of young adults' routes off benefits receipt via integration into vocational training and employment and its determinants. The study facilitates to quantify the structure of the young adults' exits from benefits receipt by training or employment for the first time. Although the dynamics of benefits receipt and exits from receipt have already been analysed in various empirical studies, there does not exist any evidence for the transitions off receipt for young adults yet.

The theoretical discussion of the routes off benefits receipts deals on the one hand with allocation processes on the labour market. From this perspective the young adults' chances to get off benefits receipt are influenced by opportunities structures in the vocational training system and employment system that are depending on individual resources. On the other hand, different approaches on the development of dependency in benefits receipt are discussed. It is assumed that young beneficiaries are not willing to leave benefits receipt and be engaged in training or employment if there are little financial incentives for employment or when they have learned to deal with benefits receipt in long-term receipt or their family of origin. This assumption is analysed for 18- to 24-year-olds that started to receive social benefits in January 2005. The analysis is based on a combination of the survey "Life Situation and Social Security 2005" and register data of the German Federal Employment Agency for 2005 to 2007. Besides descriptive statistics the study presents evidence from multivariate hazard rate models for discrete time with dependent competing risks.

The empirical analysis shows that integration into gainful employment or vocational training in companies is not the major route off benefits receipt for young beneficiaries. In most cases the benefits episodes are ended by other reasons in the household context (e.g. re-employment of the parents or partner). However, most surveyed young beneficiaries are not detached from employment or vocational training, as high numbers of them accept job or training positions that go along with further benefits receipt. The results of the multivariate analyses indicate that the young beneficiaries' employment and training participation is dependent on individual qualifications, previous employment experience and unemployment experience, and the households' constellation. The results can be interpreted as if getting off benefits is mainly a question of individual resources and the depending opportunity structures in the labour market. Moreover, young people seem to be more likely to become detached from the labour market in benefits receipt if they cannot reach integration into gainful employment in the long run. But there is no evidence for a general risk of developing dependence in benefits receipt for the surveyed young adults.

\section{Kurzfassung}

Mit den Arbeitsmarkt- und Sozialreformen in Deutschland im Jahr 2005 stehen auch die Arbeitsmarktchancen und 
Ausbildungs- und Erwerbsbereitschaft von Jugendlichen und jungen Erwachsenen im Bezug von Arbeitslosengeld II in der öffentlichen und politischen Diskussion. Im Vordergrund steht die Wahrnehmung, dass sich junge Arbeitslosengeld-II-Empfänger angesichts eingeschränkter Beschäftigungs- und Ausbildungsperspektiven auf Dauer im Leistungsbezug „einrichten“ könnten. Deswegen ist in der Grundsicherung für Arbeitssuchende eine verstärkte Aktivierung von unter 25-Jährigen im Vergleich zu älteren Personen vorgesehen, mit dem Ziel, eine schnelle Erwerbsaufnahme und einen Kurzzeitbezug von Arbeitslosengeld II zu fördern. Vor diesem Hintergrund beschäftigt sich die vorliegende Studie mit den Abgangswegen von jungen Grundsicherungsempfängern aus dem Arbeitslosengeld-II-Bezug durch eine Ausbildungs- und Arbeitsmarktbeteiligung und dessen Determinanten. Die Analysen gestatten es, das erste Mal die Strukturen der erwerbsbezogenen Abgangswege aus dem Leistungsbezug für junge Erwachsene belastbar zu quantifizieren. Obwohl die Dynamik im Grundsicherungsbezug und Abgänge aus dem Bezug bereits in mehreren Studien untersucht wurden, existieren bislang keine empirischen Befunde zu den Übergängen junger Leistungsempfänger in Beschäftigung und Ausbildung.

Die Frage, welche individuellen, sozialen und familiären Faktoren die Abgangswege von jungen Erwachsenen aus dem Arbeitslosengeld-II-Bezug in Ausbildung und Beschäftigung beeinflussen, kann zum einen anhand von Theorien zu Allokationsprozessen am Ausbildungs- und Arbeitsmarkt diskutiert werden. Eine Ausbildungs- oder Erwerbsaufnahme hängt aus dieser Perspektive von den individuellen Ressourcen und Opportunitäten am Arbeitsmarkt ab. Zum anderen werden armutstheoretische Theorien angeführt, die auf verschiedene Gründe für einen verhaltensbedingten Verbleib im Leistungsbezug rekurrieren. Angenommen wird, dass junge Erwachsene willentlich im Bezug von Arbeitslosigkeit und Inaktivität am Arbeitsmarkt verbleiben, wenn sie kaum finanzielle Anreize für eine Erwerbsaufnahme haben oder im Leistungsbezug oder in ihrer Herkunftsfamilie Handlungsmuster in Abhängigkeit erlernt haben. Diese unterschiedlichen Erklärungsansätze werden für 18- bis 24-Jährige der Eintrittskohorte in den Arbeitslosengeld-II-Bezug im Januar 2005 untersucht. Datenbasis der Studie ist eine Kombination der Befragungsstudie „Lebenssituation und Soziale Sicherung 2005“ und Prozessdaten der Bundesagentur für Arbeit für den Beobachtungszeitraum 2005 bis 2007. Neben Deskriptionen werden multivariate Analysen mit Hazardratenmodellen für diskrete Zeit und abhängige konkurrierende Risiken durchgeführt.

Die Ergebnisse der Studie zeigen, dass die Aufnahme einer existenzsichernden Beschäftigung oder betrieblichen Ausbildung durch die jungen Erwachsenen eine vergleichsweise geringe Rolle für eine Beendigung des Arbeitslosen-
geld-II-Bezugs spielt. Die Bezugsepisoden werden überwiegend aus anderen Gründen in der Bedarfsgemeinschaft (z.B. Beschäftigung der Eltern oder des Partners) abgeschlossen. Dennoch ist der Großteil der betrachteten jungen Erwachsenen nicht fern von Arbeit und Ausbildung, denn viele der jungen Arbeitslosengeld-II-Empfänger akzeptieren auch Ausbildungs- oder Beschäftigungspositionen, mit denen sie keine vollständige Existenzsicherung ohne Arbeitslosengeld-II-Bezug erzielen können. Die multivariaten Analysen zeigen, dass die Erwerbsbeteiligung der jungen Grundsicherungsempfänger und ihre Abgangschancen aus dem Arbeitslosengeld-II-Bezug vorrangig eine Frage der Qualifikationen, der bisherigen Erwerbs- und Arbeitslosigkeitserfahrung und der Haushaltskonstellation sind. Die Befunde legen die Interpretation nahe, dass vor allem die von den individuellen Ressourcen abhängigen Opportunitäten am Arbeits- und Ausbildungsmarkt die Abgangswege aus dem Leistungsbezug beeinflussen. Die Analysen weisen auf ein erhöhtes Risiko hin, dass sich junge Erwachsene aus dem Arbeitsmarkt in den Transferbezug zurückziehen könnten, wenn sie wiederholt auf Dauer keine finanzielle Eigenständigkeit erzielen können. Ein generelles Risiko, dass sich junge Erwachsene im Arbeitslosengeld-II-Bezug einrichten könnten, besteht jedoch nicht.

Danksagung I would like to thank Marita Jacob, Martin Abraham, the anonymous referees and the editor Thomas Hinz for their helpful comments on the paper.

\section{Literatur}

Aassve, A., Iacovou, M., Mencarini, L.: Youth poverty and transition to adulthood in Europe. Demogr. Res. Monogr. 15, 21-50 (2006)

Achatz, J., Popp, S., Schels, B.: Junge Erwachsene im Rechtskreis SGB II. Gefördert, gefordert und beforscht. Jugend Beruf Ges. 58, 4048 (2007)

Aigner, D.J., Cain, G.G.: Statistical theories of discrimination in labor markets. Ind. Labor Relat. Rev. 30, 175-187 (1977)

Andreß, H.J., Strengmann-Kuhn, W.: Warum arbeiten wenn der Staat zahlt? Über das Arbeitsangebot unterer Einkommensschichten. Z. Sozialreform 43, 505-526 (1997)

Arrow, K.J.: Models of discrimination. In: Arrow, K.J. (ed.) Collected Papers of Kenneth J. Arrow. Westview Press, Boulder (1975)

Bane, M.J., Ellwood, D.T.: Welfare Realities. From Rhetoric to Reform. Harvard University Press, Cambridge (1994)

Baumert, J., Stanat, P., Watermann, R.: Herkunftsbedingte Disparitäten im Bildungswesen. Vertiefende Analysen im Rahmen von PISA 2000. VS Verlag für Sozialwissenschaften, Wiesbaden (2006)

Becker, G.S.: Investment in human capital: a theoretical analysis. Eur. J. Polit. Econ. 70, 9-49 (1962)

Becker, G.S.: The Economic Approach of Human Behaviour. University Press of Chicago, Chicago (1976)

Becker, R.: Klassenlage und Bildungsentscheidungen. Eine empirische Anwendung der Wert-Erwartungstheorie. Köln. Z. Soziol. Soz.psychol. 52, 450-474 (2000)

Berg, G.J. van den: Duration models: specification, identification and multiple durations. In: Heckman, J.J., Leamer, E. (eds.) Handbook of Econometrics, vol. 5. Elsevier, Amsterdam (2001) 
Bernardi, F.: Is it a timing or a probability effect? Four simulations and an application of transition rate models to the analysis of unemployment exit. Qual. Quant. 35, 231-252 (2001)

Blossfeld, H.P.: Sensible Phasen im Bildungsverlauf - Eine Längsschnittanalyse über die Prägung von Bildungskarrieren durch den gesellschaftlichen Wandel. Z. Pädagog. 34, 45-63 (1988)

Boudon, R.: Education, opportunity and social inequality: changing prospects in Western society. Wiley, New York (1974)

Büchel, F., Spieß, C.K.: Kindertageinrichtungen und Müttererwerbstätigkeit - Neue Ergebnisse zu einem bekannten Zusammenhang. Vierteljahreshefte zur Wirtschaftsforschung 71, 95-113 (2002)

Buhr, P.: Dynamik von Armut. Dauer und biographische Bedeutung von Sozialhilfebezug. Westdeutscher Verlag, Opladen (1995)

Buhr, P., Weber, A.: Social assistance and social change in Germany. In: Leisering, L., Walker, R. (eds.) The Dynamics of Modern Society. Poverty, Policy and Welfare. The Policy Press, Bristol (1998)

Dietrich, H., Abraham, M.: Eintritt in den Arbeitsmarkt. In: Abraham, M., Hinz, T. (eds.) Arbeitsmarktsoziologie. Probleme, Theorien, empirische Befunde. VS Verlag für Sozialwissenschaften, Wiesbaden (2005)

Dietrich, H., Gerner, H.-D.: The determinants of apprenticeship training with particular reference to business expectations. Z. Arbeitsmarktforsch. 40, 221-233 (2007)

Dietrich, H., Kleinert, C.: Re-employment-But what kind of job? Job prospects of young unemployed. In: Bellmann, L., Sadowski, W. (eds.) Bildungsökonomische Analysen mit Mikrodaten. Beiträge zur Arbeitsmarkt- und Berufsforschung, vol. 295, pp. 185-203. Institut für Arbeitsmarkt und Berufsforschung, Nürnberg (2005)

Drilling, M.: Young urban poor. In: Abstiegsprozesse in den Zentren der Sozialstaaten. VS Verlag für Sozialwissenschaften, Wiesbaden (2004)

Eichhorst, W., Grienberger-Zingerle, M., Konle-Seidl, R.: Activation policies in Germany. From status protection to basic income support. In: Eichhorst, W., Kaufmann, O., Konle-Seidl, R. (eds.) Bringing the jobless into work? Experiences with activation schemes in Europe and the US, pp. 17-67. Springer, Berlin (2008)

Erikson, R., Jonsson, J.O.: Can Education Be Equalized? The Swedish Test Case in Comparative Perspective. Westview Press, Boulder (1996)

Furlong, A.: Vulnerable Youth: Perspectives on Vulnerability in Education, Employment and Leisure in Europe-International Expert Report. Council of Europe, Strasbourg (2000)

France, A.: From being to becoming: the importance of tackling youth poverty in transitions to adulthood. Soc. Policy. Soc. 7, 495-505 (2008)

Gangl, M.: Sozialhilfebezug und Arbeitsmarktverhalten Eine Längsschnittanalyse der Übergänge aus der Sozialhilfe in den Arbeitsmarkt. Z. Soziol. 27, 212-232 (1998)

Garcia, M., Kazepov, Y.: Why some people are more likely to be on social assistance than others. In: Saraceno, C. (ed.) Social Assistance Dynamics in Europe: National and Local Poverty Regimes, pp. 127-172. The Policy Press, Bristol (2002)

Gebauer, R.: Arbeit gegen Armut. Grundlagen, historische Genese und empirische Überprüfung des Armutsfallentheorems. VS Verlag für Sozialwissenschaften, Wiesbaden (2007)

Gebauer, R., Vobruba, G.: The open unemployment trap: life at the intersection of labour market and welfare state. The case of Germany. J. Soc. Policy 32, 571-587 (2003)

Gebauer, R., Petschauer, H., Vobruba, G.: Wer sitzt in der Armutsfalle? Selbstbehauptung zwischen Sozialhilfe und Arbeitsmarkt, 2nd edn. Sigma, Berlin (2003)

German Bundestag: Bundestagsdrucksache 15/1516. Entwurf eines Vierten Gesetzes für moderne Dienstleistungen am Arbeitsmarkt. Gesetzentwurf der Fraktionen SPD und Bündnis 90/Die Grünen (2003)
German Federal Employment Agency: Arbeitsmarkt in Zahlen. Statistik der Bundesagentur für Arbeit, Nürnberg (2007)

German Federal Employment Agency: Statistik der Grundsicherung für Arbeitssuchende nach dem SGB II. Zeitreihe zu Eckwerte SGB II nach Ländern (2008)

German Consortium for Coverage of Education: Bildung in Deutschland 2008: Ein indikatorengestützter Bericht mit einer Analyse zu Übergängen zum Übergang im Anschluss an den Sekundarbereich I. Bertelsmann, Bielefeld (2008)

Graf, T.: Die Hälfte war zwei Jahre lang durchgehend bedürftig. Bedarfsgemeinschaften 2005 und 2006. IAB-Kurzbericht Nr. 17/2007. Institut für Arbeitsmarkt- und Berufsforschung, Nürnberg (2007)

Hammer, T.: Consequences of unemployment in the transition from youth to adulthood in a life course perspective. Youth Soc 27, 450-468 (1996)

Heady, C.: Labour market transitions and social exclusion. J. Eur. Soc. Policy 7, 119-128 (1997)

Hill, D.H., Axinn, W.G., Thornton, A.: Competing hazards with shared unmeasured risk factors. Sociol. Method. 23, 245-277 (1993)

Hoynes, H.W.: Local labor markets and welfare spells: do demand conditions matter? Rev. Econ. Stat. 82, 351-368 (2000)

Kieselbach, T.: Long-term unemployment among young people: the risk of social exclusion. Am. J. Community Psychol. 32, 69-79 (2003)

Klett-Davies, M.: Going it alone? Lone motherhood in late modernity. Ashgate, Aldershot (2007)

Konietzka, D.: Vocational training and the transition to the first job in Germany: new risks at labor market entry? In: Bills, D.B. (ed.) The Sociology of Job Training, pp. 161-195. Elsevier, Amsterdam (2003)

Lauterbach, W., Sacher, M.: Erwerbseinstieg und erste Erwerbsjahre. Ein Vergleich von vier Geburtskohorten. Köln. Z. Soziol. Soz.psychol. 53, 258-282 (2001)

Leisering, L., Leibfried, S.: Time and Poverty in Western Welfare States: United Germany in Perspective. Cambridge University Press, Cambridge (1999)

Leisering, L., Voges, W.: Erzeugt der Wohlfahrtsstaat seine eigene Klientel? Eine theoretische und empirische Analyse von Armutsprozessen. Köln. Z. Soziol. Soz.psychol. 32, 446-472 (1992)

Lewis, O.: The culture of poverty. In: Moynihan, D.P. (ed.) On Understanding Poverty, pp. 187-220. Basic Books, New York (1968)

Lex, T.: Berufswege Jugendlicher zwischen Integration und Ausgrenzung. Juventa Verlag, München (1997)

Lietzmann, T.: Bedarfsgemeinschaften im SGB II: Warum Alleinerziehende es besonders schwer haben. IAB-Kurzbericht 12/2009. Institut für Arbeitsmarkt- und Berufsforschung, Nürnberg (2009)

Ludwig, M.: Armutskarrieren. Zwischen Aufstieg und Abstieg im Sozialstaat. Westdeutscher Verlag, Opladen (1996)

Ludwig-Mayerhofer, W., Behrend, O., Sondermann, A.: Auf der Suche nach der verlorenen Arbeit: Arbeitslose und Arbeitsvermittler im neuen Arbeitsmarktregime. UVK, Konstanz (2009)

McGinnity, F., Hillmert, S.: Persisting class inequality? Comparing class-specific unemployment in early working life in Britain and West Germany. Eur. Soc. 6, 383-408 (2004)

McGinnity, F., Mertens, A., Gundert, S.: A bad start? Fixed-term contracts and the transition from education to work in Germany. Eur. Sociol. Rev. 21, 359-374 (2005)

Meßmann, S., Bender, S., Rudolph, H., Hirseland, A., Bruckmeier, K., Wübbeke, C., Dundler, A., Städele, D., Schels, B.: Lebenssituation und Soziale Sicherung 2005 (LSS 2005). IABQuerschnittsbefragung SGB II. FDZ Datenreport 04/2008. Institut für Arbeitsmarkt- und Berufsforschung, Nürnberg (2008)

Mincer, J., Ofek, H.: Interrupted work careers: depreciation and restoration of human capital. J. Hum. Resour. 17, 3-23 (1982)

Möhring-Hesse, M.: Wie die Faust aufs Auge - Jugendsozialarbeit im aktivierenden Sozialstaat. Jugend Beruf Ges. 57, 9-18. (2006) 
Murray, C.: Losing Ground: American Social Policy 1950-1980. Basic Books, New York (1984)

Phelps, E.S.: The statistical theory of racism and sexism. Am. Econ. Rev. 62, 659-661 (1972)

Popp, S., Schels, B.: Do you feel excluded? The subjective experience of young state benefit recipients in Germany. J. Youth Stud. 11, 165-191 (2008)

Popp, S., Schels, B., Wenzel, U.: Junge Erwachsene im Rechtskreis SGB II: Viele können noch gar nicht aktiviert werden. IABKurzbericht 26/2006, Institut für Arbeitsmarkt- und Berufsforschung, Nürnberg (2006)

Scherer, S.: Early career patterns: a comparison between Great Britain and West Germany. Eur. Sociol. Rev. 17, 119-144 (2001)

Scherer, S.: Stepping-stones or traps? The consequences of labour market entry positions on future careers in West Germany, Great Britain and Italy. Work Employ. Soc. 18, 369-394 (2004a)

Scherer, S.: Erwerbseintritt und Berufsverlauf. Westdeutschland, Italien und Großbritannien im Vergleich. Peter Lang, Frankfurt a.M. (2004b)

Schmelzer, P.: The consequences of job mobility for future earnings in early working life in Germany-placing indirect and direct job mobility into institutional context. Eur. Sociol. Rev. (2010, online first)

Schneider, H., Uhlendorff, A.: Transitions from welfare to employment. Does the ratio between labor income and social assistance matter? Schmollers Jahrbuch. Z. Wirtsch.- Sozialwiss. 125, 51-61 (2005)

Schwarze, J., Raderschall, S.: Welfarisation in Deutschland: Werden die Familien abhängig von der Sozialhilfe? ifb-Materialien 1/02. Staatsinstitut für Familienforschung an der Universität Bamberg, Bamberg (2002)

Solga, H.: Ohne Abschluss in die Bildungsgesellschaft: Die Erwerbschancen gering qualifizierter Personen aus ökonomischer und soziologischer Perspektive. Verlag Barbara Budrich, Opladen (2005)

Solga, H.: Lack of training-the employment opportunities of lowskilled persons from a sociological and micro-economic perspective. In: Mayer, K.U., Solga, H. (eds.) Skill FormationInterdisciplinary and Cross-National Perspectives, pp. 173-205. Cambridge University Press, New York (2008)

Sørensen, A.B., Kalleberg, A.L.: An outline of a theory of matching persons to jobs. In: Grusky, B.D. (ed.) Social Stratification: Class,
Race, and Gender in Sociological Perspective, pp. 362-369. Westview Press, Boulder (1994)

Spence, M.: Job market signalling. Q. J. Econ. 87, 355-374 (1973)

Steele, F., Diamond, I., Wang, D.: The determinants of the duration of contraceptive use in China: a multi-level multinomial discretehazard modeling approach. Demography 33, 12-23 (1996)

Steele, F., Goldstein, H., Browne, W.: The determinants of the duration of contraceptive use in China: a multi-level multinomial discretehazard modeling approach. Stat. Model. 4, 145-159 (2004)

Stiglitz, J.: The theory of "screening", education, and the distribution of income. Am. Econ. Rev. 65, 283-300 (1975)

Stocké, V.: Explaining educational decision and effects of families' social class position: an empirical test of the Breen-Goldthorpe model of educational attainment. Eur. Sociol. Rev. 23, 505-519 (2007)

Strengmann-Kuhn, W.: Armut trotz Erwerbstätigkeit in Deutschland Folge der „Erosion des Normalarbeitsverhältnisses“. In: Barlösius, E., Ludwig-Mayerhofer, W. (eds.) Die Armut der Gesellschaft, pp. 131-150. Leske + Budrich, Opladen (2001)

Strengmann-Kuhn, W.: Inequalities in earnings and child rearing: what is the gender aspect of poverty? Intervention. J. Econ. 4, 181-201 (2007)

Walther, A.: Regimes of youth transition: choice, flexibility and security in young people's experiences across different European contexts. Young 14, 119-139 (2006)

Wilde, J.: Was reizt Sozialhilfeempfänger zum Ausstieg? Eine empirische Untersuchung mit dem Niedrigeinkommens-Panel. Jahrb. Natl.ökon. Stat. 223, 719-742 (2003)

Wilson, W.J. (ed.): The Ghetto Underclass: Social Science Perspectives. Sage, Newbury Park (1993)

Brigitte Schels studied Social Sciences at the University of ErlangenNuremberg where she obtained her degree in 2005. Afterwards she worked on her doctoral dissertation on "Social Benefits Receipt during School-to-Work Transition" that was supervised at the University of Mannheim. She holds a research position at the Institute for Employment Research (Institut für Arbeitsmarkt- und Berufsforschung), Nuremberg and at the Chair of Sociology and Empirical Social Research at the University of Erlangen-Nuremberg. Her research interests are in youth poverty and young people's transitions into vocational training and employment. 